\title{
Cell composition of the head kidney of European chub (Squalius cephalus L. )
}

\author{
Elżbieta Kondera
}

Received - 10 April 2014/Accepted - 08 October 2014. Published online: 31 December 2014; @Inland Fisheries Institute in Olsztyn, Poland Citation: Kondera E. 2014 - Cell composition of the head kidney of European chub (Squalius cephalus L. ) - Arch. Pol. Fish. 22: 271-280.

\begin{abstract}
The aim of the present study was to perform quantitative and qualitative evaluations of developing blood cells in the head kidney of European chub, Squalius cephalus (L.). Twenty-one types of hematopoietic precursors and mature cells were identified in head kidneys isolated from ten juvenile fish. The lymphoid lineage was the most abundant, followed by granuloid, erythroid, thrombocytoid, blast, and monocytoid cells. The lymphocyte was the most frequently occurring cell in the kidney and the most numerous of the lymphoid cells. The neutrophilic lineage was the most numerous among the granuloid cells. The erythropoietic series comprised five stages (erythroblasts: basophilic, polychromatic, orthochromatic; young and mature erythrocytes), more than the numbers of developmental stages of any other lineages. Juvenile cells were more abundant than mature stages in the head kidney. Only mature eosinophils and thrombocytes were found in chub hematopoietic tissue. The cellular composition in chub hematopoietic tissue was similar to that in other fish species.
\end{abstract}

Keywords: head kidney, chub, hematopoiesis, blood cells

\section{Introduction}

The chub, Squalius cephalus (L.) is a freshwater Cyprinid fish widely distributed throughout Europe and Asia (Arlinghaus and Wolter 2003). It inhabits

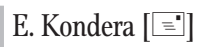

Department of Animal Physiology

University of Natural Sciences and Humanities

ul. Prusa 12, 08-110 Siedlce, Poland

e-mail: elzbieta.kondera@uph.edu.pl flowing and standing waters and is characterized by a high tolerance to organic water pollution (Mancini et al. 2005). The use of chub as bioindicator has already been reported in field studies assessing the environmental quality of inland waters affected variously by anthropogenic activities (Krča et al. 2007, Frenzilli et al. 2008). Age, growth, feeding, length-weight relationships, and reproduction features of the chub inhabiting European and Turkish waters have been reported (Karataş and Can 2005, Koç et al. 2007, Raikova-Petrova et al. 2012), but there is no substantial information in the literature on blood cell formation in the hematopoietic tissue of this fish. Head kidney tissue is known to be sensitive to various impacts because of its high cell turnover rate (Kondera and Witeska 2013), so it can be used as a bioindicator, and it can provide early warning signs of environmental degradation. According to Fijan (2002a, 2002b), Soldatov (2005), and Gangopadhyay and Homechaudhuri (2011), the pronephros, or head kidney, is a basic organ forming the blood elements, and it is also the reservoir of blood cells. The head kidney is also an important endocrine organ, homologous to mammalian adrenal glands, releasing catecholamines, corticosteroids, and other hormones. Thus, the pronephros is an important organ with key regulatory functions and the central organ for immune-endocrine interactions and even neuroimmunoendocrine connections (Tort et al. 2003). 
The histology and ultrastructure of head kidney tissue has been described for various fish species (Esteban et al. 1989, Meseguer et al. 1990, Abdel-Aziz et al. 2010, Santos et al. 2011). However, quantitative data on the cellular composition of haematopoietic organs in teleosts are scarce and incomplete (Peters and Schwarzer 1985, Własow and Dąbrowska 1989, Fijan 2002b, Som et al. 2009, Gangopadhyay and Homechaudhuri 2011).

Basic hematopoietic structures and mechanisms in fishes are similar to those operating in other vertebrates (Fijan 2002a, 2002b), and all hematopoietic cell types are very similar to those of mammals (Chen and Zon 2009). Hematopoiesis is a complex process in which haematopoietic stem cells (HSCs), the most immature elements of the hematopoietic hierarchy, proliferate and differentiate into various classes of hematopoietic progenitor cells. These progenitor cells further have been shown to be able to differentiate into mature blood cells: erythrocytes, lymphocytes, thrombocytes, granulocytes, and monocytes (Peters and Schwarzer 1985, Zuasti and Ferrer 1989, Własow and Dąbrowska 1989, Fijan 2002a, 2002b, Kobayashi et al. 2006, Som et al. 2009). All vertebrates (including fish) have primitive and definitive waves of hematopoiesis, but HSCs are only produced by the definitive wave. The primitive wave occurs in two intraembryonic locations called the intermediate cell mass (ICM) and the anterior lateral mesoderm (ALM). Primitive erythropoiesis is in the ICM, whereas myelopoiesis initiates in the ALM. After circulation starts at $24 \mathrm{~h}$ post-fertilization, hematopoiesis shifts to the posterior blood island for a brief period. The definitive wave starts in the aorta-gonadmesonephros (AGM). There are three different HSC migration and colonization events that begin two days post-fertilization: AGM progenitor cells migrate to the caudal hematopoietic tissue, which is an intermediate site of blood development; the thymus, which is a site of lymphocyte maturation; and the developing kidney marrow, which is the larval and adult location for production of all hematopoietic cell types (Davidson and Zon 2004, Chen and Zon 2009).
However, in mammals and other higher vertebrates all myeloid cells proliferate and mature in the bone marrow, while in teleosts there is more than one hematopoietic site, including the pronephros, mesonephros, epicardium, spleen, thymus, and the serosa of the middle part of the intestine (Homechaudhuri and Jah 2001, Soldatov 2005, Zapata et al. 2006, Santos et al. 2011). The present study aimed to identify blood cells in head kidney of $S$. cephalus quantitatively and qualitatively.

\section{Materials and Methods}

European chub (S. cephalus) with a body mass of $89.8 \pm 2.6 \mathrm{~g}$ and length of $19.8 \pm 1.1 \mathrm{~cm}$, were used for the experiment in October. The fish were harvested from a rearing pond at the Inland Fisheries Institute in Żabieniec and transported to the laboratory of the Department of Animal Physiology, University of Natural Sciences and Humanities in Siedlce. The fish were stocked into a $300 \mathrm{l}$ flow-through tank where they were acclimated for one month to laboratory conditions. Water temperature was $18-20^{\circ} \mathrm{C}$, dissolved oxygen saturation level was $70-80 \%$, and $\mathrm{pH}$ was 6.9. The fish were fed Aller Classic feed daily at a ratio of $1 \%$ of body mass.

Ten juvenile fish were sacrificed by cutting the spinal cord quickly with sharp scissors. The head kidneys were isolated, the surface of the fresh organs was blotted, and tissue was smeared gently on degreased slides. After drying for $24 \mathrm{~h}$, the smears were stained using May-Grünwald and Giemsa solutions for light microscopy examination (1000 x magnification). Five hundred blood cells were identified, counted, and their relative abundance was calculated for each fish. The cells were identified according to terminology in Fijan (2002a) and Kondera (2011).

The results were expressed as percentages of each type of cell in the total number of blood cells examined. The identified cells were then grouped into the main cell lineages, each of which included various developmental stages. Cells that did not match any of the lineage stages described above or that were 
not identified because of damage were categorized as unclassified. Fields with crowded or damaged cells were excluded. Areas of kidney imprints with numerous mature erythrocytes (possibly blood vessel contents) were also omitted.

\section{Results}

Twenty-one types of hematopoietic precursors and mature cells were identified in the $S$. cephalus head kidney (Table 1). Microscopy observation detected the following haemopoietic series: unidentified blast cells, erythroid, granuloid, lymphoid, monocytoid, and thrombocytoid. Early blast cells of various lineages were morphologically similar, so they were included in one common group to avoid identification bias. Blast cells were larger than mature cells. Cell shape varied from round to oval. The blast cells had a large (usually round) nucleus that filled from 50 to $90 \%$ of the cell volume and an intensely blue cytoplasm.

The erythropoietic series comprised five stages (erythroblasts: basophilic, polychromatic, orthochromatic; young and mature erythrocytes), which was more than the numbers of developmental stages of any of the other lineages (Fig. 1). In the present study erythroblasts were more numerous than erythrocytes. The basophilic erythroblast was characterized by more coarse and granular chromatin, smaller, peripheral nucleus, smaller cell size, and darker blue cytoplasm than the early blast cells. The cytoplasm of the polychromatic erythroblast was grey, and the nucleus occupied $40-60 \%$ of the cell volume. Nuclear chromatin was coarsely granular. Some early and intermediate cells were oval. The late cells of this stage were round, and were the smallest among the maturing erythroid cells. The orthochromic erythroblast typically had a rosy red cytoplasm and a round nucleus, which was more condensed than in the previous stage. The young erythrocyte was irregularly round to oval, larger than the orthochromic erythroblast with a less condensed nucleus, and was smaller than the mature erythrocyte. The mature erythrocyte was larger and more elongated and had a more intensely rosy-red cytoplasm
Table 1

Frequency (\%) of various blood cells in the head kidney of European chub (S. cephalus) $(\mathrm{n}=10$, mean $\pm \mathrm{SD})$

\begin{tabular}{ll}
\hline \hline Stage & Frequency $(\%)$ \\
\hline \hline Blast cells & $9.79 \pm 3.73$ \\
Erythroid & $12.59 \pm 3.65$ \\
basophilic erythroblast & $0.58 \pm 0.25$ \\
polychromatic erythroblast & $6.88 \pm 0.95$ \\
orthochromatic erythroblast & $0.28 \pm 0.11$ \\
young erythrocyte & $3.07 \pm 0.86$ \\
mature erythrocyte & $1.78 \pm 0.55$ \\
Granuloid & $20.07 \pm 6.68$ \\
myelocyte & $5.92 \pm 3.35$ \\
metamyelocyte & $5.96 \pm 2.59$ \\
band neutrophil & $2.29 \pm 1.73$ \\
segmented neutrophil & $1.15 \pm 1.19$ \\
young progranulocyte & $1.29 \pm 1.35$ \\
basophilic metagranulocyte & $1.12 \pm 1.51$ \\
young basophil & $1.58 \pm 2.24$ \\
mature basophil & $0.31 \pm 0.39$ \\
eosinophil & $0.45 \pm 0.49$ \\
Lymphoid & $43.68 \pm 6.55$ \\
prolymphocyte & $3.96 \pm 1.30$ \\
lymphocyte & $38.08 \pm 7.17$ \\
plasmocyte & $1.77 \pm 0.88$ \\
Monocytoid & $1.37 \pm 0.87$ \\
promonocyte & $0.98 \pm 0.63$ \\
mature monocyte & $0.42 \pm 0.48$ \\
\hline \hline
\end{tabular}

and a more elongated nucleus compared to that of the young erythrocyte.

Lymphoid lineage cells were the most abundant in the chub hemopoietic tissue. Prolymphocytes, mature lymphocytes, and plasmacytes were identified in the lymphopoietic series. The prolymphocyte was a small cell, but it was larger than the lymphocyte. It had pale blue cytoplasm. The number, size, and cytoplasm color of lymphocytes varied considerably. The round nucleus filled about $80-90 \%$ of the cell volume. Lymphocytes observed in the present study were variously sized spherical cells, with basophilic cytoplasm and without granulations. The plasmacyte 


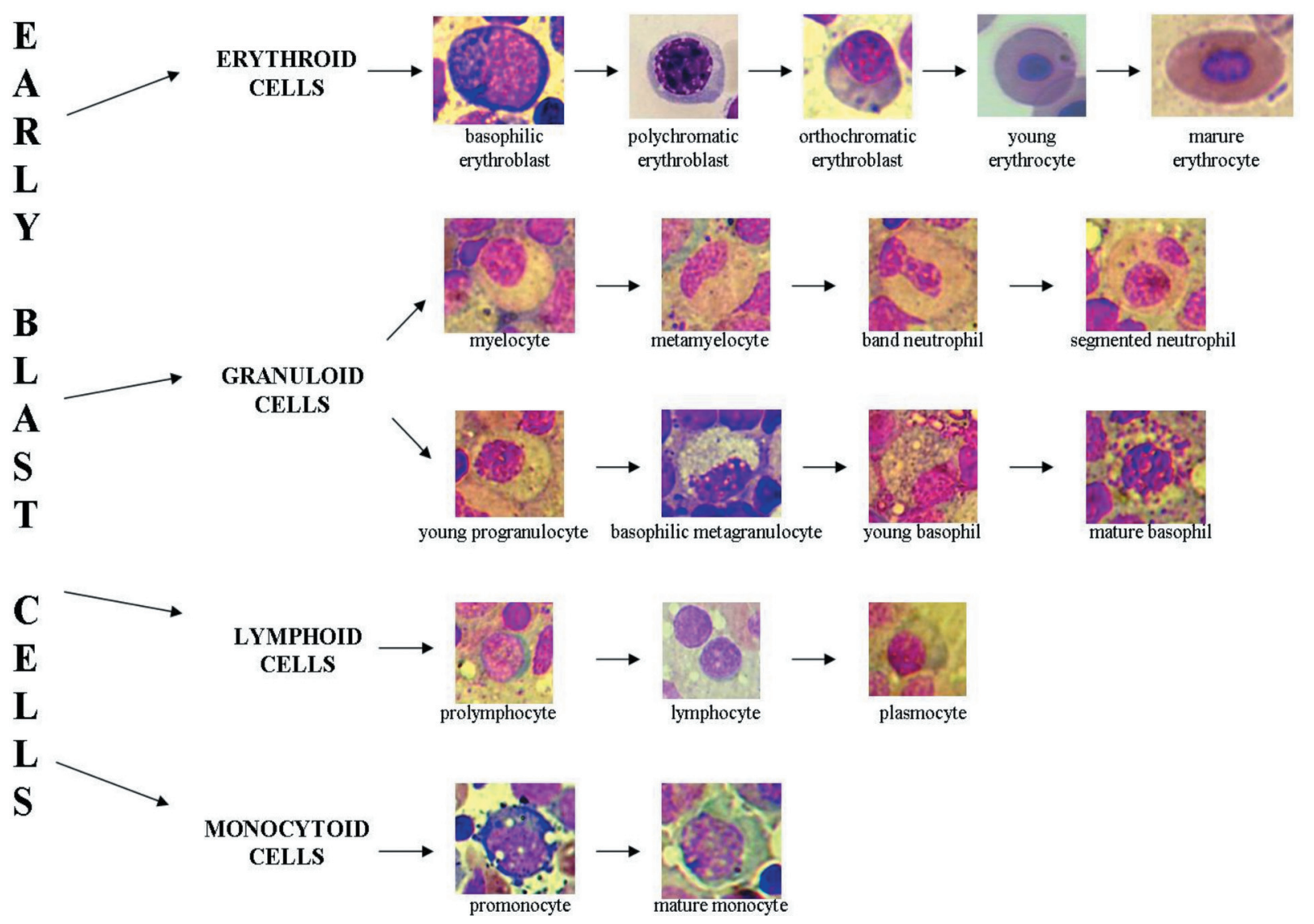

Figure 1. Diagram of European chub (S. cephalus) head kidney hematopoietic cell morphogenesis.

had an eccentrically located nucleus and deep blue cytoplasm with small peripheral pale vacuoles surrounded by darker cytoplasm. The nucleus of the plasmacyte occupied $<30 \%$ of the cell.

Granuloid cells comprised neutrophilic, basophilic, and eosinophilic series. The neutrophilic lineage was the most frequent group of granulopoietic cells. Early neutrophil precursors (myelocytes and metamyelocytes) were more numerous than mature neutrophils (band neutrophil and segmented neutrophil). The myelocyte had light bluish cytoplasm, a round and mostly eccentric nucleus which occupied $50 \%$ of the cell. The metamyelocyte nucleus was mostly eccentric, sometimes oval, and occupied $<50 \%$ of the cell volume. Small parts of the cytoplasm near the nucleus were sometimes still faintly bluish, but the rest was loaded with specific granulation. The neutrophil was characterized by ungranulated cytoplasm and a smaller, more compact band (band neutrophil) or segmented nucleus (segmented neutrophil). The lineage of basophils in chub was present regularly in the kidneys. Young basophils (young progranulocyte and basophilic metagranulocyte) were more abundant than older stages (young basophil and mature basophil). Basophilic granulocytes had a thin, barely distinguishable basophilic cytoplasmic mesh surrounded by unstained spaces, and basophilic granulation. The young progranulocyte had foamy basophilic cytoplasm with scarce fine basophilic granulation. The slightly to completely eccentric nucleus of the basophilic progranulocyte occupied $<50 \%$ of the cell and had a more condensed chromatin than the myelocyte. The basophilic metagranulocyte had a more elongated nucleus and darker foamy cytoplasm with more abundant granulation. Young basophils were characterized by the appearance of dense coarse basophilic granules. 
Granulation occupied the whole cytoplasm in the mature basophil.

Light microscopy observations indicated that the number of monocytes was small. Promonocytes predominated in the monocytoid lineage. The promonocyte had a medium blue cytoplasm. The nucleus occupied $\geq 50 \%$ of the cell. The mature monocyte had a more abundant light blue cytoplasm and an eccentric, more compact, reniform or irregularly oval nucleus. Some monocytes were of different sizes and contained many vacuoles in the cytoplasm. Precursors of eosinophil and thrombocyte cell lineages were not noted in $S$. cephalus hematopoietic tissue smears. Mature eosinophils were larger than neutrophils. The eccentrically located elliptical or lobed nucleus was small. The light blue to colorless cytoplasm presented relatively large rosy-red granules. The thrombocytes were oval or irregularly round, predominantly smaller than the lymphocytes, with a central compact nucleus, and minimal or no cytoplasm.

\section{Discussion}

In the present study the percentage of early blast cells was $9.8 \%$, similarly to the results of Kutyrev et al. (2011) for Carassius auratus gibelio (Bloch). It was higher in comparison to the different values reported for Cyprinus carpio L. (Własow and Dąbrowska 1989, Kondera 2011, Kondera et al. 2012), and Ictalurus punctatus (Rafinesque) (Fijan 2002b) (Table 2).

In this study the percentage of erythroid lineage cells $(12.7 \%)$ was similar to the results obtained by Fijan (2002b) for I. punctatus and by Kondera (2011) for $C$. carpio. On the other hand, this result was higher than values reported by Kondera et al. (2012) for C. carpio, and considerably lower than the values for $C$. carpio reported by Własow and Dąbrowska (1989). More numerous erythroid cells were reported by Som et al. (2009) for Labeo rohita (Hamilton) and Gangopadhyay and Homechaudhuri (2011) for Clarias batrachus (L.).
The erythropoietic series comprised the highest number (five) of developmental stages among all identified hematopoietic tissue cells, similarly to Dicentrarchus labrax (L.) (Esteban et al. 1989), Sparus aurata L. (Zuasti and Ferrer 1989), C. carpio and Oreochromis niloticus L. (Homechaudhuri and Jah 2001), I. punctatus (Fijan 2002a, 2002b), O. niloticus (Abdel-Aziz et al. 2010), and Centropomus parallelus Poey (Santos et al. 2011). Erythroblasts were more numerous (61.5\%) than erythrocytes (38.5\%). Similar results are in Som et al. (2009), who reported values of 41.5 and $58.5 \%$, respectively, in the head kidney of L. rohita, and Gangopadhyay and Homechaudhuri (2011), who reported values of 36 and 64\%, respectively, in C. batrachus. Considerably higher percentages of erythroblasts were reported in I. punctatus at $87.4 \%$ (Fijan 2002b) and in C. carpio at 93.8 (Kondera 2011) and 99.2\% (Własow and Dąbrowska 1989).

Lymphoid lineage cells were the most abundant in chub hemopoietic tissue at $43.9 \%$ similarly to $C$. carpio (Kondera 2011, Kondera et al. 2012). According to Deptuła and Stosik (2001), lymphoid cells are the main component of head kidney tissue. However, data obtained by various authors shows that the percentages of lymphoid cells in the head kidney differ considerably among fish species (Table 2). Prolymphocytes comprised $9.1 \%$ of the cells of lymphoid lineage, while mature lymphocytes were $87.2 \%$. Similar proportions were obtained by Kondera (2011) for C. carpio at $7.4 \%$ and $89.7 \%$ and Fijan (2002b) for I. punctatus at 5.4\% and $94.2 \%$, but Własow and Dąbrowska (1989) noted $7.4 \%$ and $47.1 \%$, while the remaining cells were classified as atypical. Kutyrev et al. (2011) noted 56.4\% prolymphocytes and $43.6 \%$ lymphocytes of lymphoid cells in C. gibelio. The frequency of plasmacytes (4\% of the lymphoid lineage) was lower that the results obtained by Własow and Dąbrowska (1989) at $20.3 \%$, but higher than Kondera (2011) at $0.7 \%$ in Cyprinus carpio (proplasmocytes and plasmocytes combined). Fijan (2002b) noted only plasmacytes, which comprised $0.4 \%$ of the lymphoid cells. Granuloid cells comprised $20.1 \%$ of all cells in the head kidney hematopoietic tissue of $S$. cephalus. 
Table 2

Frequency (\%) of various hematopoietic cells in the head kidney of fish (according to various authors)

\begin{tabular}{|c|c|c|c|c|c|c|c|}
\hline Stage & $\begin{array}{l}\text { Carassius } \\
\text { auratus } \\
\text { gibelio }\end{array}$ & $\begin{array}{l}\text { Clarias } \\
\text { batrachus }\end{array}$ & $\begin{array}{l}\text { Cyprinus } \\
\text { carpio }\end{array}$ & $\begin{array}{l}\text { Cyprinus } \\
\text { carpio }\end{array}$ & $\begin{array}{l}\text { Cyprinus } \\
\text { carpio }\end{array}$ & $\begin{array}{l}\text { Ictalurus } \\
\text { punctatus }\end{array}$ & $\begin{array}{l}\text { Labeo } \\
\text { rohita }\end{array}$ \\
\hline Blast cells & 12.7 & - & 3.9 & 2.10 & 3.7 & 2.8 & - \\
\hline Erythroid & - & 58.4 & 37 & 13.14 & 3.1 & 13.0 & 56 \\
\hline basophilic erythroblast & - & 9 & 9.33 & 1.78 & - & 3.03 & 9.41 \\
\hline polychromatic erythroblast & - & 8.53 & 15.90 & 8.28 & - & 4.61 & 6.90 \\
\hline orthochromatic erythroblast & - & 3.49 & 10.55 & 3.07 & - & 3.70 & 7.03 \\
\hline young erythrocyte & - & 9.13 & - & 0.28 & - & - & 9.48 \\
\hline mature erythrocyte & - & 7.87 & 0.30 & 0.58 & - & - & 11.14 \\
\hline Granuloid & 30.5 & - & 44.1 & 25.06 & - & 23.1 & - \\
\hline myelocyte & 6.0 & & 3.4 & 8.40 & & 452 & \\
\hline metagranulocyte & 6.7 & 1716 & 1.38 & 7.32 & 152 & 4.53 & 2518 \\
\hline band neutrophil & 2.9 & 17.10 & - & 4.67 & 10.2 & 1675 & 20.18 \\
\hline segmented neutrophil & 1.9 & & - & 3.49 & & 10.15 & \\
\hline young progranulocyte & - & - & - & 0.20 & & & - \\
\hline basophilic metagranulocyte & - & - & - & 0.40 & 25 & 085 & - \\
\hline young basophil & - & - & - & 0.20 & Z.5 & 0.85 & - \\
\hline mature basophil & - & - & - & 0.43 & & & - \\
\hline eosinophil & 5.7 & - & 39.3 & 0.20 & 0.0 & 0.02 & - \\
\hline Lymphoid & 56.4 & 12.85 & 13.69 & 39.00 & 54.0 & 41.3 & 62.64 \\
\hline prolymphocyte & 31.8 & - & 0.98 & 2.88 & - & 2.20 & - \\
\hline lymphocyte & 24.6 & - & 6.20 & 35.50 & - & 38.01 & - \\
\hline proplasmocyte & - & - & 0.53 & 0.36 & - & - & - \\
\hline plasmocyte & - & - & 0.93 & 0.30 & - & 0.15 & - \\
\hline Monocytoid & - & - & 0.2 & 0.98 & 1.1 & 0.91 & - \\
\hline promonocyte & - & - & 0.00 & 0.40 & - & - & - \\
\hline mature monocyte & - & - & 0.20 & 0.58 & - & - & - \\
\hline Thrombocyte & - & - & - & 18.26 & 20.4 & 19.3 & - \\
\hline Reference & $\begin{array}{l}\text { Kutyrev } \\
\text { et al. (2011) }\end{array}$ & $\begin{array}{l}\text { Gangopadhyay } \\
\text { and } \\
\text { Homechaudhuri } \\
\text { (2011) }\end{array}$ & $\begin{array}{l}\text { Własow and } \\
\text { Dąbrowska } \\
(1989)\end{array}$ & $\begin{array}{l}\text { Kondera } \\
\text { (2011) }\end{array}$ & $\begin{array}{l}\text { Kondera } \\
\text { et al. (2012) }\end{array}$ & $\begin{array}{l}\text { Fijan } \\
(2002 b)\end{array}$ & $\begin{array}{l}\text { Som } \\
\text { et al. (2009) }\end{array}$ \\
\hline
\end{tabular}

Similar results were reported by Fijan (2002b), Kondera (2011), and Kondera et al. (2012), but, according to Własow and Dąbrowska (1989), C. carpio head kidney contained $44 \%$ granuloid cells. Kutyrev et al. (2011) also noted more granulocytes in $C$. auratus gibelio at $30.5 \%$.

The neutrophilic lineage was the most frequent group of granuloid cells (15.3\%). The term "neutrophil" is applied by most researchers (Własow and Dąbrowska 1989, Fijan 2002a, 2002b, Davidson and Zon 2004), but some authors describe the same cells as "heterophil" (Zuasti and Ferrer 1988, Meseguer et al. 1990; Lehmann et al. 1994). Similar results were obtained by Kondera et al. (2012) in $C$. carpio $(15.2 \%)$, while higher values were reported by Gangopadhyay and Homechaudhuri (2011) in $C$. batrachus at $17.2 \%$, Kutyrev et al. (2011) in C. a. gibelio $17.5 \%$, Kondera (2011) in C. carpio at $23.9 \%$, 
and Som et al. (2009) in L. rohita at 25.2\%. On the contrary, Własow and Dąbrowska (1989) noted considerably fewer neutrophilic cells at only $4.8 \%$. In the present study early neutrophil precursors (myelocytes and metamyelocytes) were the most frequent neutrophilic cells (comprising 38.6 and $38.9 \%$ of all neutrophils). Higher values were noted by Własow and Dąbrowska (1989) at 71.1 and 28.9\%, while lower percentages of these cells (35.1 and 30.6\%) were reported by Kondera (2011), 34.3 and $38.3 \%$ by Kutyrev et al. (2011), and Fijan (2002b) reported $21.3 \%$ (total neutrophilic progranulocytes and neutrophilic metagranulocytes in one group). The morphology of early neutrophils was similar to that described by, among others, Meseguer et al. (1990) for D. labrax and Kobayashi et al. (2006) for Carassius auratus langsdorfii (Temminck \& Schlegel). Własow and Dąbrowska (1989) named the same cells promyelocyte and myelocyte (without metamyelocyte stages), and Fijan (2002b) refers to them as the neutrophilic progranulocyte and neutrophilic metagranulocyte. Mature neutrophils comprised 22\% of all the neutrophilic lineage. Similar results of $27.4 \%$ were obtained by Kutyrev et al. (2011) for C. a. gibelio. Kondera (2011) and Fijan (2002b) noted higher levels of these cells with totals in C. carpio of 34.3 and $I$. punctatus of $78.7 \%$, respectively. On the other hand, Własow and Dąbrowska (1989) did not observe mature neutrophils in C. carpio head kidney. The lineage of basophils in chub was regularly present in kidneys comprising $4.3 \%$ of the hematopoietic cells. Basophilic series cells are usually very scarce in both fish hematopoietic tissue and the peripheral blood (Peters and Schwarzer 1985, Zuasti and Ferrer 1989). Własow and Dąbrowska (1989) did not observe such cells in C. carpio pronephros. Fijan (2002b), Kondera (2011), and Kondera et al. (2012) reported that they comprised 1-2.5\% of head kidney hematopoietic cells. Young basophils (55.9\%) in S. cephalus were more abundant than older stages (44.1\%), which was similar to common carp (Kondera 2011). Meseguer et al. (1990) observed the following basophil stages in $D$. labrax: basophilic myelocytes, basophilic metamyelocytes, and mature basophils. Similar types of cells were reported by Zuasti and Ferrer (1988) in $S$. aurata. Only $0.4 \%$ of mature eosinophils was found in smears of hematopoietic tissue of S. cephalus (Fig. 2). This was similar to the results obtained by Fijan (2002b) and Kondera (2011), but significantly less in comparison to values reported by Własow and Dąbrowska (1989), which were near 39\% (35.0\% eosinophil-young and $4.2 \%$ eosinophil-adult). At the same time, Własow and Dąbrowska (1989) noted considerably fewer cells of neutrophilic lineage, so it is possible that they included all cells with rosy-red cytoplasm in the eosinophil lineage. According to Lehmann et al. (1994), neutrophilic granulocytes also sometimes presented with fine acidophilic structures in the cytoplasm. In the present study, only cells with clearly visible coarse eosinophilic granules were classified as eosinophils, according to Fijan (2002b), while cells with rosy-red cytoplasmic inclusions but without distinct granular structure were classified as neutrophils. Meseguer et al. (1990) noted eosinophilic myelocytes and eosinophilic metamyelocytes in $D$. labrax. L. The eosinophil lineage in C. a. gibelio head kidney included cells at various stages of differentiation: $2.6 \%$ myelocytes; $2.4 \%$ metamyelocytes; $0.5 \%$ stab; $0.2 \%$ segmented cells (Kutyrev et al. 2011).

The frequency of monocytoid cells present in the pronephros $(1.4 \%)$ was similar to that reported by Fijan (2002b) for I. punctatus and Kondera (2011) and Kondera et al. (2012) for C. carpio. A lower abundance of monocytes was noted by Własow and Dąbrowska (1989). In this study, the promonocytes predominated this lineage (70.2\%) and mature monocytes comprised almost $28.8 \%$ of all monocytoid cells. Different results were obtained for common carp with $40.8 \%$ young monocytes and $59.2 \%$ mature monocytes (Kondera 2011), while Własow and Dąbrowska (1989) did not observe promonocytes in C. carpio head kidney.

Only mature thrombocytes were found in S. cephalus hematopoietic tissue comprising $12.4 \%$ of cells. Fijan (2002b) did not observe thrombocyte precursors either. The frequency of thrombocytes in chub head kidney was lower in comparison to the results reported by Kondera (2011) and Kondera et al. (2012) for C. carpio and by Fijan (2002 b) for I. punctatus. Własow and Dąbrowska (1989) 


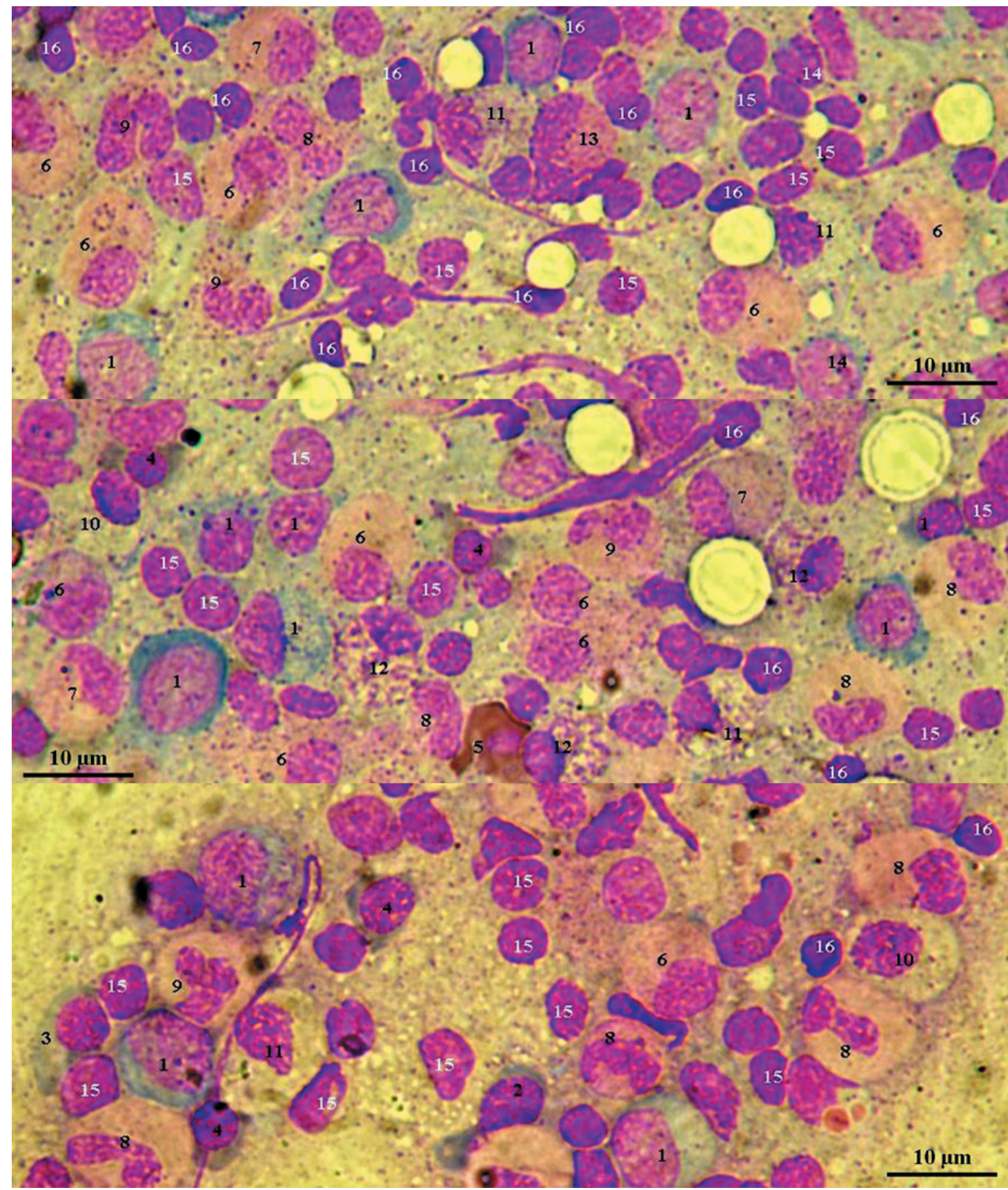

Figure 2. Blood cells in European chub (S. cephalus) head kidney: blast cell (1); basophilic erythroblast (2); polychromatic erythroblast (3); orthochromatic erythroblast (4); mature erythrocyte (5); myelocyte (6); metamyelocyte (7); band neutrophil (8); segmented neutrophil (9); basophilic metagranulocyte (10); young basophil (11); mature basophil (12); eosinophils (13); prolymphocyte (14); lymphocyte (15); thrombocyte (16).

observed no thrombocytes in C. carpio head kidney. There is little information about the development of fish thrombocytes. The nomenclature and morphology of thrombocyte precursors are unclear. Catton (1951) suggests that thrombocytopoiesis is similar to lymphocytopoiesis and that both cell types are closely related. According to Zuasti and Ferrer (1988), the thrombocyte lineage included prothrombocytes and thrombocytes. However, Esteban et al. (1989) observed immature prothrombocytes, mature prothrombocytes, and mature thrombocytes in D. labrax (based on an 
investigation of cell ultrastructure using an electron microscope).

In conclusion, the cellular composition of hematopoietic tissue in various fish species is similar (Table 2), but there are quantitative differences. The proportion of various blood cells in fish is a very labile parameter that depends on many factors, including season, physicochemical water parameters, water contamination, stressors, age, sex, different periods of the reproductive cycle, and diseases. It is obvious that the composition of hematopoietic tissue and the frequency of various cell lineages also vary even in the same fish species and that this reflects the adaptation of organisms to variable environmental conditions. Nonetheless, this issue in fish requires further study.

\section{References}

Abdel-Aziz E-S.H., Abdu S.B.S., Ali T.E-S., Fouad H.F. 2010 - Haemopoiesis in the head kidney of tilapia, Oreochromis niloticus (Teleostei: Cichlidae): a morphological (optical and ultrastructural) study - Fish Physiol. Biochem. 36: 323-336.

Arlinghaus R., Wolter C. 2003 - Amplitude of ecological potential: chub Leuciscus cephalus (L.) spawning in an artificial lowland canal - J. Appl. Ichthyol. 19: 52-54.

Catton W.T. 1951 - Blood cell formation in certain Teleost fish - Blood. 6: 39-60.

Chen A.T., Zon L.I. 2004 - Zebrafish Blood Stem Cells - J. Cell. Biochem. 108: 35-42.

Davidson A.J., Zon L.I. 2004 - The definitive (and primitive) guide to zebrafish hematopoiesis - Oncogene 23: 7233-7246.

Deptuła M., Stosik W., Travniček M. 2001 - Studies on the number and ingesting ability of thrombocytes in sick carp (Cyprinus carpio L.) - Vet. Med. 46: 12-16.

Esteban M.A., Meseguer J., Garcia Ayala A., Agulleiro B. 1989 - Erythropoiesis and thrombopoiesis in the head-kidney of the sea bass (Dicentrarchus labrax L.): an ultrastructural study - Arch. Histol. Cytol. 52: 407-19.

Fijan N. 2002a - Morphogenesis of blood cell lineages in channel catfish - J. Fish Biol. 60: 999-1014.

Fijan N. 2002b - Composition of main haematopoietic compartments in normal and bled channel catfish - J. Fish Biol. 60: 1142-1154.

Frenzilli G., Falleni A., Scarcelli V., Del Barga I., Pellegrini S., Savarino G., Mariotti V., Benedetti M., Fattorini D., Regoli F., Nigro M. 2008 - Cellular responses in the cyprinid Leuciscus cephalus from a contaminated freshwater ecosystem - Aquat. Toxicol. 89: 188-96.

Gangopadhyay K., Homechaudhuri S. 2011 - Descriptive characteristics of haemopoietic cell lineages in a facultative air breathing fish Clarias batrachus (L.) - Turk. J. Zool. 35: 737-746.

Homechaudhuri S., Jah A. 2001 - A technique to evaluate the erythropoietic efficiency in fish - Asian Fish. Sci. 14: 453-455.

Karataş M., Can M.F. 2005 - Growth, mortality and yield of chub (Leuciscus cephalus L., 1758) population in Almus Dam Lake - Turk. J. Vet. Anim. Sci. 5: 729-733.

Kobayashi I., Sekiya M., Moritomo T., Ototakeb M., Nakanishia, T. 2006 - Demonstration of hematopoietic stem cells in ginbuna carp (Carassius auratus langsdorfii) kidney - Dev. Comp. Immunol. 30: 1034-1046.

Koç H.T., Erdoğan Z., Tinkci M., Treer T. 2007 - Age, growth and reproductive characteristics of chub, Leuciscus cephalus (L., 1758) in the İkizcetepeler Dam Lake (Balýkesir), Turkey - J. Appl. Ichthyol. 23: 19-24.

Kondera E. 2011 - Haematopoiesis in the head kidney of common carp (Cyprinus carpio L.): a morphological study - Fish Physiol. Biochem. 37: 355-362.

Kondera E., Witeska M. 2013 - Cadmium and copper reduce hematopoietic potential in common carp (Cyprinus carpio L.) head kidney - Fish Physiol. Biochem. 39: 755-764.

Kondera E., Dmowska A., Rosa M., Witeska M. 2012 - The effect of bleeding on peripheral blood and head kidney hematopoietic tissue in common carp (Cyprinus carpio) Turk. J. Vet. Anim. Sci. 36: 169-175.

Krča S., Žaja R., Čalić V., Terzić S., Grubešić M.S., Ahel M., Smital T. 2007 - Hepatic biomarker responses to organic contaminants in feral chub (Leuciscus cephalus) - laboratory characterization and field study in the Sava River, Croatia - Environ. Toxicol. Chem. 26: 2620-2633.

Kutyrev I.A., Pronin N.M., Dugarov Z.N. 2011 - Composition of leucocytes of the head kidney of the Crucian Carp (Carassius auratus gibelio, Cypriniformes: Cyprinidae) as affected by invasion of Cestode Digramma interrupta (Cestoda; Pseudophyllidea) - Biology Bulletin. 38: 653-657.

Mancini L., Caimi S., Ciardullo S., Zeiner M., Bottoni P., Tancioni L., Caudatella S., Caroli S. 2005 - A pilot study on the contents of selected pollutants in fish from the Tiber River (Rome) - Microchem. J. 79: 171-175.

Meseguer J., Esteban M.A., Garcia A.A., Lopez Ruiz A., Agulleiro B. 1990 - Granulopoiesis in the head-kidney of the sea bass (Dicentrarchus labrax L.): an ultrastructural study - Arch. Histol. Cytol. 53: 287-96.

Peters G., Schwarzer R. 1985 - Changes in hemopoietic tissue of rainbow trout under influence of stress - Dis. Aquat. Org. 1: 1-10. 
Raikova-Petrova G., Hamwi N., Petrov I. 2012 - Spawning, sex ratio and relationship between fecundity, length, weight and age of chub (Squalius cephalus L., 1758) in the Middle Stream of Iskar River (Bulgaria) - Acta Zool. Bulg. 64: 191-197.

Santos A.A., Gutierre R.C., Antoniazzi M.M., Ranzani-Paiva M.J.T., Silva M.R.R., Oshima C.T.F., Egami M.I. 2011 Morphocytochemical, immunohistochemical and ultrastructural characterization of the head kidney of fat snook Centropomus parallelu - J. Fish Biol. 79: 1685-1707.

Soldatov A.A. 2005 - Peculiarities of organization and functioning of the fish red blood system - J. Evol. Biochem. Physiol. 41: 272-281.

Som M., Kundu N., Bhattacharyya S., Homechaudhuri S. 2009 - Evaluation of hemopoietic responses in Labeo rohita Hamilton following acute copper toxicity Toxicol. Environ. Chem. 91: 87-98.

Tort L., Balasch J.C., Mackenzi S. 2003 - Fish immune system. A crossroads between innate and adaptive responses - Inmunologia 22: 277-286.

Własow T., Dąbrowska H. 1989 - Cellular changes in the blood and haemopoietic tissues of common carp exposed to sublethal concentration of ammonia - Aquat. Living Resour. 2: 169-174.

Zapata A., Diez B., Cejalvo T., Gutierrez-de Frias C., Cortes A. 2006 - Ontogeny of the immune system of fish - Fish Shellfish Immunol. 20: 126-136.

Zuasti A., Ferrer C. 1988 - Granulopoiesis in the head kidney of Sparu auratus - Arch. Histol. Cytol. 51: 425-431.

Zuasti A., Ferrer C. 1989 - Haemopoiesis in the head kidney of Sparus auratus - Arch. Histol. Cytol. 52: 249-55. 